\title{
EFFECTS OF AMINOGLYCOSIDE ANTIBIOTICS ON INITIATION OF VIRAL RNA-DIRECTED PROTEIN SYNTHESIS
}

\author{
Akira Okuyama, Takashi Watanabe and Nobuo Tanaka \\ Institute of Applied Microbiology, University of Tokyo, Tokyo, Japan
}

(Received for publication December 9, 1971)

\begin{abstract}
Streptomycin, kanamycin, gentamicin, and kasugamycin were observed to inhibit $\mathrm{f} 2$ phage RNA-directed protein synthesis in an Escherichia coli system. When the reaction mixture was allowed to translate viral RNA for 5 minutes before addition of antibiotics, the synthesis was completely blocked by streptomycin or thiopeptin; but significant synthesis continued in the presence of kasugamycin, kanamycin and gentamicin. The results suggested that kasugamycin, kanamycin and gentamicin may inhibit initiation, and streptomycin may interfere with both chain initiation and elongation. Thiopeptin may affect chain elongation. The binding of fMet-tRNA to $70 \mathrm{~S}$ ribosomes in the presence of $\mathrm{f} 2$ RNA was inhibited by streptomycin, kanamycin, gentamicin, and kasugamycin. The release of $\mathrm{fMet}-\mathrm{t} R \mathrm{NA}$ from the initiation complex was significantly induced by streptomycin, kanamycin, and gentamicin; but not by kasugamycin. The results indicated that the inhibition by kasugamycin of $30 \mathrm{~S}$ initiation complex formation may result in the apparent inhibition of $70 \mathrm{~S}$ initiation complex formation. And the apparent inhibition by streptomycin, kanamycin, and gentamicin of $70 \mathrm{~S}$ initiation complex formation may be caused by breakdown of the complex and inhibition of ribosomal dissociation. The effects of streptomycin, kanamycin, and gentamicin were more significant with the initiation complex formed on washed $70 \mathrm{~S}$ ribosomes than with the complex formed on unwashed $70 \mathrm{~S}$ ribosomes. The ribosomal proteins washed out in $1 \mathrm{M} \mathrm{NH}{ }_{4} \mathrm{Cl}$ protected the target sites from the antibiotic actions. The $\mathrm{T}$ factor- and messenger-dependent binding of Ala-tRNA to the ribosomes was significantly affected by streptomycin, but not by kanamycin, gentamicin, and kasugamycin.
\end{abstract}

The site of action of aminoglycoside antibiotics has been identified as the $30 \mathrm{~S}$ ribosomal subunit ${ }^{1 \sim 6,12)}$, but the nature of disturbances induced in the translation mechanism seems to be complicated. The results reported by various investigators appear to be controversial ${ }^{7 \sim 11}$.

Luzzatro et al. ${ }^{7)}$ observed the accumulation of monosomes in $E$. coli cultures treated with streptomycin, and suggested that the antibiotic interrupts the ribosomal cycle at the initiation of protein synthesis. In vitro streptomycin did not prevent the binding of fMet-tRNA to the $30 \mathrm{~S}$ subunit-mRNA complex and the subsequent joining of the $50 \mathrm{~S}$ subunit, but caused release of the fMet-tRNA bound in the $70 \mathrm{~S}$ ribosomes ${ }^{9 \sim 11}$. In contrast, another aminoglycoside kasugamycin was demonstrated to block formation of the $30 \mathrm{~S}$ initiation complex ${ }^{12}$.

The activity of aminoglycoside antibiotics, including streptomycin, kanamycin, gentamicin and kasugamycin, on initiation of viral RNA-directed protein synthesis 
has been compared in an in vitro system, and the results are presented in this publication.

\section{Materials and Methods}

E. coli tRNA, ATP, GTP, PEP and pyruvate kinase were the products of Boehringer. ${ }^{14} \mathrm{C}$-Valine and -methionine, and ${ }^{3} \mathrm{H}$-alanine and -methionine were purchased from Daiichi Chemical Co. Streptomycin, kanamycin, kasugamycin and gentamicin were supplied by National Institute of Health, Tokyo. Thiopeptin was kindly given by Dr. H. SakaI, Fujisawa Pharmaceutical Co. Puromycin was the product of Lederle. Folinic acid was purchased from General Biochemicals.

The preparation of S-30 fraction, ribosomes and initiation factor from E. coli Q13 followed the method of OHTA et al. ${ }^{18)}$. The ribosomes were washed in $0.1 \mathrm{M}$ $\mathrm{NH}_{4} \mathrm{Cl}$ or $1 \mathrm{M} \mathrm{NH}_{4} \mathrm{Cl}$, containing $50 \mathrm{~mm}$ Tris- $\mathrm{HCl}$, pH 7.5, $10 \mathrm{mM} \mathrm{Mg}(\mathrm{AcO})_{2}$ and $6 \mathrm{~mm}$ 2-mercaptoethanol. The former is termed unwashed ribosomes and the latter the washed ribosomes in this paper. RNA of $\mathrm{f} 2$ phage was prepared by the phenol extraction method of NATHANS et al. ${ }^{19)} \quad$ E. coli tRNA was acylated with ${ }^{14} \mathrm{C}$-methionine or ${ }^{3} \mathrm{H}$-alanine by the method of Hershey and $\mathrm{THACH}^{20)}$. E. coli tRNA was fractionated by BD cellulose chromatography. E. coli RNA $_{F}^{\text {Met }}$ was kindly given by Dr. S. Nishimura, National Cancer Center, Tokyo. E. coli T factor was generously supplied by Dr. Y. KAzIRo, Institute of Medical Science, University of Tokyo.

\section{Results}

The $f 2$ phage RNA-directed protein synthesis was studied in an $E$. coli system. The incorporation of valine was inhibited by aminoglycoside antibiotics. At the concentration of $2 \times 10^{-5} \mathrm{M}, 95 \%$ inhibition was observed with streptomycin,

Fig. 1. Inhibition by aminoglycoside antibiotics of $f 2$ phage RNAdirected protein synthesis.

The reaction mixture contained: $50 \mathrm{~mm}$ Tris$\mathrm{HCl}$, pH 7.5, $160 \mathrm{mM} \mathrm{NH}_{4} \mathrm{Cl}, 8 \mathrm{mM} \mathrm{Mg}(\mathrm{AcO})_{2}, 6 \mathrm{mM}$ 2-mercaptoethanol, $3 \mathrm{mg}$ protein $/ \mathrm{ml} \mathrm{S}-30$ fraction of E. coli $\mathrm{Q} 13$ extracts, $500 \mu \mathrm{g} / \mathrm{ml}$ of $\mathrm{f} 2$ RNA, $150 \mu \mathrm{g} / \mathrm{ml} \mathrm{E}$. coli tRNA, $0.2 \mu \mathrm{Ci} / \mathrm{m} 1{ }^{14} \mathrm{C}$-valine $(165$ $\mu \mathrm{Ci} / \mu$ mole $), 0.025 \mathrm{~mm}$ amino acids except valine, $2 \mathrm{~mm}$ ATP, $5 \mathrm{~mm}$ PEP, $20 \% \mathrm{~g} / \mathrm{ml}$ pyruvate kinase, and $0.1 \mathrm{mM}$ GTP ; $0.2 \mathrm{ml}$ in each tube. It was incubated at $37^{\circ} \mathrm{C}$ for 30 minutes. The TCAinsoluble radioactivity was determined with correction for the values obtained in parallel mixtures without messenger.

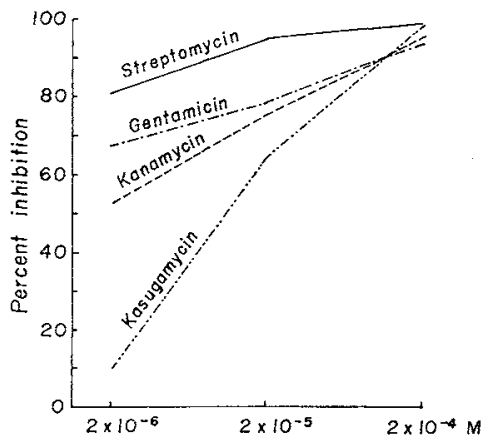

$76 \%$ inhibition with kanamycin, $78 \%$ inhibition with gentamicin, and $65 \%$ inhibition with kasugamycin, when the antibiotics were added at the start of protein synthesis (Fig. 1).

Fig. 2. Kinetics of inhibition by antibiotics of $f 2$ RNA-directed protein synthesis.

The reaction mixture was as described in the legend of Fig. 1.

$\downarrow$ Addition of antibiotics

${ }^{14} \mathrm{C}$-valine

incorporated

pmoles/tube control

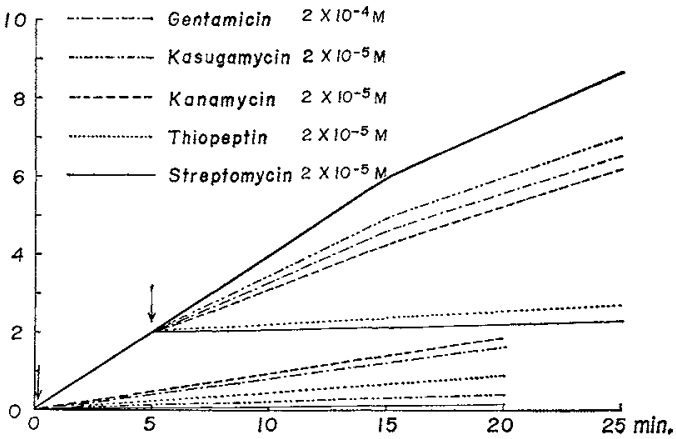


Fig. 3. Effect of aminoglycosides on binding of fMet-tRNA to $70 \mathrm{~S}$ ribosomes in the presence of $f 2$ RNA.

The reaction mixture contained: 50 $\mathrm{mm}$ Tris- $\mathrm{HCl}, \mathrm{pH} 7.5,60 \mathrm{mM} \mathrm{NH}_{4} \mathrm{Cl}$, $6 \mathrm{~mm} \mathrm{Mg}(\mathrm{AcO})_{2}, 10 \mathrm{~mm}$ 2-mercaptoethanol, $2 \mathrm{mg} / \mathrm{ml}$ washed $70 \mathrm{~s}$ ribosomes, $0.6 \mathrm{mg} / \mathrm{ml}$ initiation factor, $150 \mu \mathrm{g} / \mathrm{ml} \mathrm{f}$ ${ }^{24} \mathrm{C}$-Met-tRNA $(300,000 \mathrm{cpm} / \mathrm{mg}), 1 \mathrm{mg} /$ $\mathrm{ml} f 2$ RNA, $0.2 \mathrm{~mm}$ GTP; $0.1 \mathrm{ml}$ in each tube. It was incubated at $37^{\circ} \mathrm{C}$ for 15 minutes. The radioactivity, collected on Millipore filter, was assayed with corrections for values without messenger.

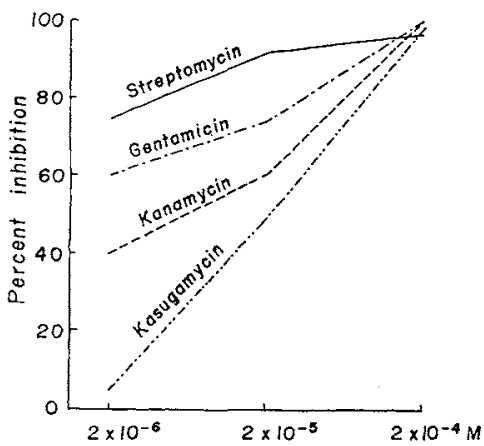

The reaction mixture was allowed to translate viral RNA for 5 minutes and then the antibiotics were added. Further protein synthesis was completely inhibited by streptomycin. But the grade of inhibiton by kasugamycin, kanamycin and gentamicin was significantly less than that observed when

Table 1. Effect of streptomycin and kasugamycin on binding of fMet-tRNA to unwashed $70 \mathrm{~S}$ ribosomes in the presence of $\mathrm{f} 2$ phage $\mathrm{RNA}$

\begin{tabular}{c|c|c|c}
\hline fMet-tRNA & Antibiotics & $\begin{array}{c}\text { Met-tRNA } \\
\text { bound } \\
\text { pmoles) }\end{array}$ & $\begin{array}{c}\% \\
\text { Inhibi- } \\
\text { tion }\end{array}$ \\
\hline $\begin{array}{c}\text { Unfractionated } \\
\text { (14C-labelled) }\end{array}$ & Streptomycin $2 \times 10^{-5} \mathrm{M}$ & 5.16 & 38 \\
& Kasugamycin $2 \times 10^{-4}$ & 1.50 & 82 \\
\hline \multirow{2}{*}{$\begin{array}{c}\text { Fractionated } \\
\text { ('H-labelled) }\end{array}$} & Streptomycin $2 \times 10^{-5} \mathrm{M}$ & 7.11 & \\
& Kasugamycin $2 \times 10^{-4}$ & 1.97 & 16 \\
\hline
\end{tabular}

The binding of IMet-tRNA was performed in the reaction mixture, as described in the lengend of Fig. 3 , in which washed $70 \mathrm{~S}$ ribosomes and initiation factors were replaced by $2 \mathrm{mg} / \mathrm{ml}$ unwashed $70 \mathrm{~S}$ ribosomes. In the case fractionated tRNA ${ }_{F}^{\text {Met }}, 30$ $\mu \mathrm{g} / \mathrm{ml}$ f-3H-Met-tRNAF $(1,024 \mu \mathrm{Ci} / \mu$ mole $)$ was used.

Fig. 4. Release by streptomycin of fMet-tRNA from the $70 \mathrm{~S}$ initiation complex. str : streptomycin, \%:\% breakdown of the $70 \mathrm{~S}$ initiation complex.

The $70 \mathrm{~S}$ initiation complex was formed as described in the legend of Fig. 3. At 15 minutes, streptomycin was added at the concentration of $2 \times 10^{-5} \mathrm{M}$ and further incubated for 15 minutes.

(I) Unwashed ribosomes (70S) and f-14C-Met-tRNA (unfractionated) were used.

(II) Unwashed $70 \mathrm{~S}$ ribosomes and $\mathrm{f}^{3} \mathrm{H}$-Met-tRNA (fractionated) were used.

(III) Washed $70 \mathrm{~S}$ ribosomes, initiation factors and f-14C-Met-tRNA (unfractionated) were used.

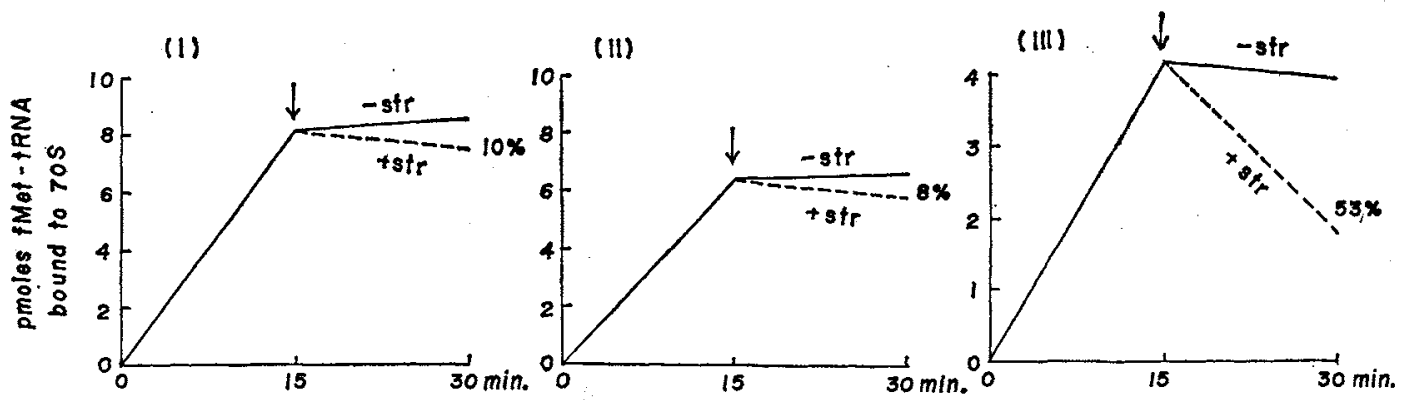

they were addded at the beginning of protein synthesis (Fig. 2). The concentration of kasugamycin employed was 10 times that for other aminoglycosides since it is much less effective in inhibiting bacterial growth and protein synthesis ${ }^{12}$. Thiopeptin, a peptide antibiotic, has been demonstrated to block chain elongation ${ }^{13)}$. It was observed to exhibit the same tendency of inhibition as streptomycin (Fig. 2). From these results we suggest that kasugamycin, kanamycin, and gentamicin inhibit a process at or near initiation more markedly than they affect chain elongation. Streptomycin may interfere with chain elongation or with both chain initiation and elongation.

The binding of fMet-tRNA to washed $70 \mathrm{~S}$ ribosomes in the presence of $f 2$ RNA and initiation factors was significantly affected by streptomycin, kanamycin, genta- 
micin, and kasugamycin. The extents of inhibition were comparable with those of protein synthesis (Figs. 1 and 3).

In the experiments, in which washed ribosomes and initiation factors were replaced by unwashed ribosomes, the inhibition by streptomycin of fMet-tRNA binding was significantly reduced. However, virtually the same order of inhibition was observed with kasugamycin (Table 1). No significant difference was found with fractionated fMettRNA $A_{F}$ and with unfractionated fMet-tRNA.

Streptomycin, kanamycin, and gentamicin
Table 2. The reactivity of $f$ Met- $-\mathrm{RNA} \mathrm{A}_{\mathrm{F}}$ in the $70 \mathrm{~S}$ initiation complex to puromycin

\begin{tabular}{|c|c|}
\hline System & $\begin{array}{l}\text { fMet-puromycin } \\
\text { formed (pmoles) }\end{array}$ \\
\hline Complete & 4.64 \\
\hline -f 2 RNA & 1.01 \\
\hline - puromycin & 0.48 \\
\hline $200 \mu \mathrm{g} / \mathrm{ml}$ & 3.06 \\
\hline + Ala-tRNAAIa $50 \mu \mathrm{g} / \mathrm{ml}$ & 3.39 \\
\hline$+t_{R N A}^{A l a b}$ & 3.62 \\
\hline
\end{tabular}

The $70 \mathrm{~S}$ initiation complex was formed with unwashed $70 \mathrm{~S}$ ribosomes as described in Tabie 1. At 15 minutes, puromycin was added at the concentration of $2 \times 10^{-4} \mathrm{M}$, and the reac. tion mixture was further incubated for $15 \mathrm{mi}$ nutes. The reaction was terminated by addition of $1 \mathrm{ml}$ of $0.1 \mathrm{M}$ sodium acetate, $\mathrm{pH} 5.5$, and fMet-puromycin was extracted with ethyl acetate.

Table 3. Effect of antibiotics on release of fMet-tRNA from $70 \mathrm{~S}$ initiation complex and on binding of Ala-tRNA to it

\begin{tabular}{|c|c|c|c|c|c|}
\hline & \multirow{2}{*}{ Antibiotics } & \multicolumn{2}{|c|}{$f-14 \mathrm{C}-\mathrm{Met}-\mathrm{tRNA}$} & \multicolumn{2}{|c|}{${ }^{3} \mathrm{H}-\mathrm{Ala}-\mathrm{tRNA}$} \\
\hline & & $\begin{array}{l}\text { Bound } \\
\text { (pmoles) }\end{array}$ & $\begin{array}{c}\text { Release } \\
(\%)\end{array}$ & $\begin{array}{l}\text { Bound } \\
\text { (pmoles) }\end{array}$ & $\begin{array}{l}\text { Inhibition of } \\
\text { binding (\%) }\end{array}$ \\
\hline \multirow{6}{*}{$\begin{array}{l}\text { Initiation complex formed } \\
\text { with washed } 70 S \text { and } \\
\text { initiation factors. }\end{array}$} & None & 1.26 & & 1.03 & \\
\hline & Streptomycin $2 \times 10^{-5} \mathrm{M}$ & 0.63 & 50 & 0.36 & 65 \\
\hline & Kanamycin $\quad 2 \times 10^{-5}$ & 0.64 & 49 & 0.52 & 50 \\
\hline & Gentamicin $2 \times 10^{-5}$ & 0.73 & 42 & 0.50 & 51 \\
\hline & Kasugamycin $2 \times 10^{-4}$ & 1.17 & 7 & 0.98 & 5 \\
\hline & Thiopeptin $2 \times 10^{-5}$ & 1.22 & 3 & 0.04 & 96 \\
\hline \multirow{6}{*}{$\begin{array}{l}\text { II. Initiation complex formed } \\
\text { with unwashed } 70 \mathrm{~S} \\
\text { ribosomes. }\end{array}$} & None & 7.54 & & 5.82 & \\
\hline & Streptomycin $2 \times 10^{-5} \mathrm{M}$ & 6.11 & 19 & 2.33 & 60 \\
\hline & Kanamycin $2 \times 10^{-5}$ & 6.11 & 19 & 5.35 & 8 \\
\hline & Gentamicin & 6.03 & 20 & 4.83 & 17 \\
\hline & Kasugamycin $2 \times 10^{-4}$ & 7.40 & 2 & 5.83 & 0 \\
\hline & Thiopeptin $2 \times 10^{-5}$ & 6.94 & 8 & 0.00 & 100 \\
\hline
\end{tabular}

Exp. I. The reaction mixture contained : $50 \mathrm{~mm}$ Tris- $\left.\mathrm{HCl}, \mathrm{pH} 7.5,60 \mathrm{mM} \mathrm{NH}_{4} \mathrm{Cl}, 6 \mathrm{~mm} \mathrm{Mg(AcO}\right)_{2}, 10 \mathrm{~mm} 2-$ mercaptoethanol, $2 \mathrm{mg} / \mathrm{m} 170 \mathrm{~S}$ initiation complex, $10 \mu \mathrm{g} / \mathrm{ml} \mathrm{T}$ factor, $0.2 \mathrm{~mm} \mathrm{GTP},{ }^{3} \mathrm{H}-\mathrm{Ala}-\mathrm{tRNA}(3,000 \mu \mathrm{Ci} / \mu \mathrm{mole})$ and antibiotics; $0.1 \mathrm{ml}$ in each tube. It was incubated at $37^{\circ} \mathrm{C}$ for 10 minutes. The radioactivity of ${ }^{3} \mathrm{H}-\mathrm{Ala}-$ tRNA was determined with correction for values without $T$ factor. The $70 \mathrm{~S}$ initiation complex was formed as described in Fig. 3 and was pelletted and washed by ultracentrifugation.

Exp. II. The $70 \mathrm{~S}$ initiation complex was formed as described in Tabie 1. At 15 minutes, the tubes were cooled to $0{ }^{\circ} \mathrm{C}$ and $10 \mu \mathrm{g} / \mathrm{ml} \mathrm{T}$ factor, $0.2 \mathrm{mM} \mathrm{GTP},{ }^{3} \mathrm{H}$-Ala-tRNA and antibiotics were added in $0.2 \mathrm{ml}$ final volume. It was incubated further for 10 minutes at $37^{\circ} \mathrm{C}$. The radioactivity of ${ }^{14} \mathrm{C}$ and ${ }^{3} \mathrm{H}$ was determined with correction for values without messenger.

were observed to induce release of up to $60 \%$ of fMet-tRNA bound to the $70 \mathrm{~S}$ initiation complex (Fig. 4 and Table 3). The grade of induced breakdown of the $70 \mathrm{~S}$ initiation complex was less than that of inhibition of the $70 \mathrm{~S}$ initiation complex formation. It indicated that the apparent inhibition by these antibiotics of initiation complex formation may be caused not only by breakdown of the complex but also by the inhibition of ribosomal dissociation ${ }^{14)}$.

The fMet-tRNA release was much less induced by the antibiotics, when the initiation complex was formed with unwashed ribosomes; up to $20 \%$ release was observed (Fig. 4 and Table 3). Most of fMet-tRNA was puromycin-reactive in the initiation complex formed with unwashed $70 \mathrm{~S}$ ribosomes as well as with washed $70 \mathrm{~S}$ ribosomes and initiation factors. Ala-tRNA or deacylated tRNA ${ }^{\mathrm{Ala}}$ was observed not 
to stimulate the fMet-puromycin reaction. It indicated that most of fMet-tRNA was bound to the donor stie in the $70 \mathrm{~S}$ initiation complex (Table 2). The results also suggested that the ribosomal proteins washed out in $1 \mathrm{M} \mathrm{NH}_{4} \mathrm{Cl}$ may protect the target sites of the aminoglycoside antibiotics, or may exhibit a certain

\begin{abstract}
unknown functions for the activity of
\end{abstract}
Table 4. Effects of aminoglycoside antibiotics on fMet-puromycin reaction

\begin{tabular}{l|c|c}
\hline \multicolumn{1}{c|}{ Antibiotics } & $\begin{array}{c}\text { fMet-puromycin } \\
\text { formed (pmoles) }\end{array}$ & $\begin{array}{c}\% \\
\text { Inhibition }\end{array}$ \\
\hline None & 8.67 & \\
Kasugamycin $2 \times 10^{-4} \mathrm{M}$ & 8.70 & 0 \\
Kanamycin $2 \times 10^{-5}$ & 8.43 & 3 \\
Gentamicin $2 \times 10^{-5}$ & 8.26 & 5 \\
Streptomycin $2 \times 10^{-5}$ & 7.91 & 9 \\
\hline \multicolumn{2}{c}{ The assay procedure was the same as described in Table } \\
2. The aminoglycosides were added simultaneousis at 15 \\
minutes.
\end{tabular}
the antibiotics. The activity of kasugamycin on the initiation complex formation was virtually the same both with unwashed ribosomes and with washed ones (Fig. 3 and Table 1).

Kasugamycin did not induce a significant release of fMet-tRNA from the $70 \mathrm{~S}$ initiation complex, while it blocked the initiation complex formation (Table 3 and Fig. 3).

The $\mathrm{T}$ factor- and messenger-dependent binding of Ala-tRNA to $70 \mathrm{~S}$ ribosomes was inhibited by streptomycin but was not significantly affected by kasugamycin (Table 3). The results were in accordance with the assumption that streptomycin interferes with chain elongation as well as chain initiation, while kasugamycin selectively inhibits chain elongation.

The binding of Ala-tRNA was reduced by the presence of kanamycin and gentamicin with the washed ribosomes, from which fMet-tRNA was significantly released. But the binding was less affected with the unwashed ribosomes, from which less fMet-tRNA was released (Table 3). Most of fMet-tRNA was attached to the donor site in both ribosomes (Table 2). If mRNA was released by kanamycin and gentamicin concomitantly with fMet-tRNA from the ribosomes ${ }^{11}$, then mRNA-dependent AlatRNA binding did not occur, regardless of the antibiotic effects. On the contrary, if mRNA was still attached to the ribosomes ${ }^{7}$, the results indicated that kanamycin and gentamicin may inhibit Ala-tRNA binding to the initiation complex formed with washed ribosomes but may not significantly affect the binding to the ones formed with unwashed ribosomes. The discrepancy may be due to the different sensitivity of the two forms of ribosomes to the antibiotics. Formylmethionyl-puromycin formation was not significantly affected by kasugamycin, kanamycin, gentamicin, and streptomycin (Table 4).

\section{Discussion}

The results presented in this publication and the previous on $\mathrm{e}^{12)}$ indicate that kasugamycin is a selective inhibitor of initiation of protein synthesis. It inhibits the formation of $30 \mathrm{~S}$ initiation complex and subsequently the $70 \mathrm{~S}$ initiation complex formation, while the other aminoglycoside antibiotics do not significantly affect the $30 \mathrm{~S}$ initiation complex formation. Contrary to streptomycin, kasugamycin does not significantly induce release of fMet-tRNA from the initiation complex nor inhibit the binding of Ala-tRNA to the ribosomes which is dependent on $T$ factor and messenger (f 2 RNA).

Streptomycin induces release of fMet-tRNA from the $70 \mathrm{~S}$ initiation complex. The results are in accordance with those of Leiong et al..$^{9,10)}$ and those of Modollel and 
DAvis ${ }^{11)}$. It also inhibits the binding of Ala-tRNA to the ribosomes with $f 2$ RNA in the presence of $T$ factor and GTP. The results indicate that streptomycin affects chain elongation as well as chain initiation.

The release by streptomycin of fMet-tRNA from the $70 \mathrm{~S}$ initiation complex is much reduced when unwashed ribosomes are employed instead of washed ribosomes and initiation factors. The results may be in accordance with those of LenNeite and Apirion ${ }^{8)}$, who have observed that fMet-tRNA is attached to streptomycin-monosomes formed in vivo. Streptomycin, kanamycin, and gentamicin are observed to exhibit more pronounced effects with washed ribosomes than with unwashed ribosomes. The results seem to be in accordance with the view that the site of action of the aminoglycosides has to be uncovered first in vivo ${ }^{15,16)}$. The binding of ${ }^{3} \mathrm{H}$-streptomycin to ribosomes is markedly enhanced by the washing procedure with $1 \mathrm{M} \mathrm{NH}_{4} \mathrm{Cl}$ (unpublished data).

Kanamycin and gentamicin also induce release of fMet-tRNA from the $70 \mathrm{~S}$ initiation complex. The results are different from those of LELONG et al. ${ }^{9)}$ The discrepancy remains: to be elucidated. However, since the sensitivity of washed ribosomes to the antibiotics is significantly different from that of unwashed ribosomes, the discrepancy may be due to the state of ribosomes employed.

The effects of kanamycin and gentamicin on chain elongation, particularly on AlatRNA binding, have been not well established by the methods employed. However, it was demonstrated by the kinetic study that kanamycin and gentamicin affect chain initiation more markedly than chain elongation.

Streptomycin, kanamycin, neomycin and spectinomycin have been reported to inhibit: dissociation of $70 \mathrm{~S}$ ribosomes by initiation factor $\mathrm{F}_{3}{ }^{14)}$. The inhibition by streptomycin and kanamycin of the $70 \mathrm{~S}$ initiation complex formation may be the sequence of the inhibition of ribosomal dissociation. The grade of inhibition of the $70 \mathrm{~S}$ initiation complex formation is higher than the grade of induced release of fMet-tRNA from the complex. Therefore it is plausible that the inhibition by the aminoglycoside antibiotics of ribosomal dissociation and the induced brakdown of $70 \mathrm{~S}$ initiation complex result in the apparent inhibition of $70 \mathrm{~S}$ initiation complex formation.

Thiopeptin, a peptide antibiotic, has been observed to interact with $50 \mathrm{~S}$ subunit of ribosomes and interfere with both $\mathrm{T}$ and $\mathrm{G}$ factor-associated functions ${ }^{13)}$. It does not. significantly affect chain initiation nor induce breakdown of the initiation complex. But it markedly inhibits $\mathrm{T}$ factor-dependent binding of Ala-tRNA to the ribosomes with $\mathrm{f} 2$ : RNA. The results are in accordance with the previous paper ${ }^{13)}$.

\section{References}

1) Ozaki, M.; S. Mizushima \& M. Nomura : Identification and functional characterization of the protein controlled by streptomycin-resistant locus in E. coli. Nature $222: 333 \sim 339,1969$

2) BtrGe, E. A. \& C. G. KURLANd: Altered ribsomal protein streptomycin-dependent Escherichia coli. Science $166: 1282 \sim 1284,1969$

3) Dekio, S. \& R. Takata: Genetic studies of the ribosomal proteins in Escherichia coli. II. Altered $30 \mathrm{~S}$ ribosomal protein component specific to spectinomycin resistant mutants. Mol. Gen. Genetics 105: 219 224, 1969

4) MasuKawa, H. : Localization of sensitivity to kanamycin and streptomycin in $30 \mathrm{~S}$ ribosomal proteins of Escherichia coli. J. Antibiotics $22: 612 \sim 623,1969$

5) Chang, F. N. \& J. G. Flaks: Topography of the Escherichia coli $30 \mathrm{~S}$ ribosomal subunit and streptomycin binding. Proc. Nat. Acad. Sci. 67 : 1148 1155, 1970

6) Helser, T. L.; J. E. Davies \& J. E. Dahlberg: Change in methylation of $16 \mathrm{~S}$ ribosomal RNA associated with mutation to kasugamycin resistance in Escherichia coli. Nature New Biol. $233: 12 \sim 14,1971$

7) Luzzatto, L.; D. Apirion \& D. Schlessinger: Mechanism of action of streptomycin in E. coli: Interuption of the ribosome cycle at the initiation of protein synthesis. Proc. Nat. Acad. Sci. $60: 873 \sim 880,1968$. Polysome depletion and blockage of the ribosome cycle by streptomycin in Escherichia coli. J. Mol. Biol. $42: 315 \sim 335,1969$ 
8) Lennette, E. T. \& D. Apirion: The level of Fmet-tRNA on ribosomes from streptomycin treated cells. Biochem. Biophys. Res. Commun. $41: 804 \sim 811,1970$

9) Lelong, J. C.; M. A. Cousin, D. Gros, M. Grunberg-Manago \& F. Gros : Streptomycin induced release of $f$ Met-tRNA from the ribosomal initiation complex. Biochem. Biophys. Res. Commun. $42: 530 \sim 537,1971$

10) Zagorska, L.; J. Dondon, J. C. Lelong, F. Gros \& M. Grunberg-ManaGo: Decoding site of initiation transfer RNA. Biochemie $53: 63 \sim 70,1971$

11) Modollel, J. \& B. D. Davis : Breakdown by streptomycin of initiation complexes formed on ribosomes of Escherichia coli. Proc. Nat. Acad. Sci. 67: 1148 1155, 1970

12) Okuyama, A,; N. Machiyama, T. Kinoshita \& N. Tanaka: Inhibition by kasugamycin of initiation of complex formation on $30 \mathrm{~S}$ ribosomes. Biochem. Biophys. Res. Commun. 43:196 199, 1971

13) Kinoshita, T.; Y.-F. Lrov \& N. Tanaka : Inhibition by thiopeptin of ribosomal functions associated with $\mathrm{T}$ and $\mathrm{G}$ factors. Biochem. Biophys. Res. Commun. $44: 859 \sim 863,1971$

14) Garcta-Patrone, M.; C. A. Perazzolo, F. Baralle, N. S. Gonzalez \& J. D. Algranati : Studies on dissociation factor of bacterial ribosomes: Effects of antibiotics. Biochim. Biophys. Acta $246: 291 \sim 299,1971$

15) YAMAKI, H. \& N. TANAKA: Effects of protein synthesis inhibitors on the lethal action of kanamycin and streptomycin. J. Antibiotics, Ser. A $16: 222 \sim 226,1963$

16) White, J. R. \& H. L. White : Streptomycinoid antibiotics: Synergism by puromycin. Science $146: 772 \sim 773,1964$

17) Machiyama, N. : Mechanism of action of lividomycin A, a new aminoglycoside antibiotic. J. Antibiotics $24: 706 \sim 707,1971$

18) Ohta, T.; S. Sarkar \& R. E. Thach: The role of guanosine 5 -triphosphate in the initiation of peptide synthesis. III. Binding of formyl-methionyl-tRNA to ribosomes. Proc. Nat. Acad. Sci. $58: 1638 \sim 1644,1967$.

19) Nathans, D.; G. Notani, J. H. Schwartz \& N. D. Zinder: Biosynthesis of the coat protein of coliphage f 2 by $E$. coli extracts. Proc. Nat. Acad. Sci. $48: 1424 \sim 1431,1962$

20) Hershey, W. B. \& R. E. Thach : Role of guanosine 5'-triphosphate in the initiation of peptide synthesis. I. Synthesis of formylmethionyl-puromycin. Proc. Nat. Acad. Sci. $57: 759 \sim 766$, 1967 